\title{
Analysis of Wastewater Treatment Efficiency in a Soft Drinks Industry
}

\author{
Joanna Boguniewicz-Zabłocka ${ }^{1, *}$, Andrea G. Capodaglio ${ }^{2}$ and Daniel Vogel $^{1}$ \\ ${ }^{1}$ Opole University of Technology, ul. Mikołajczyka 5, 45-271Opole, Poland \\ 2 DICAr,University of Pavia, via Ferrata 3, 27100 Pavia, Italy
}

\begin{abstract}
During manufacturing processes, most industrial plants generate wastewater which could become harmful to the environment. Discharge of untreated or improperly treated industrial wastewaters into surface water could, in fact, lead to deterioration of the receiving water body's quality. This paper concerns wastewater treatment solutions used in the soft drink production industry: wastewater treatment plant effectiveness analysis was determined in terms of basic pollution indicators, such as BOD, COD, TSS and variable $\mathrm{pH}$. Initially, the performance of mechanic-biological systems for the treatment of wastewater from a specific beverages production process was studied in different periods, due to wastewater flow fluctuation. The study then showed the positive effects on treatment of wastewater augmentation by methanol, nitrogen and phosphorus salts dosed into it during the treatment process. Results confirm that after implemented modification (methanol, nitrogen and phosphorus additions) pollution removal occurs mostly with higher efficiency.
\end{abstract}

\section{Introduction}

The beverage production sector belongs to the agro-food industry. This industry is currently under consumer pressure, implementing significant changes as the result of increasing public interest in the so-called "healthy lifestyle". Products well-fitting to such a style have essentially much less sugar content, thus reducing the calorie content of drinks. Significant increase in sale volumes was recently observed in the so-called "functional waters" segment, that is, products based on ordinary spring water enriched with vitamins, minerals and/or flavoring extracts [1]. The beverage industry accounts for a notable $11.2 \%$ of the entire food sector income in Poland. Bottled water has been driving the industry for a few years, and in 2015, the public has spent nearly $12 \%$ more on it than in the previous year, with the highest increase in isotonic drinks alone. Economic forecasts predict a faster rising pace of water sales in the near future, than the industrial sector average, with the value of sales in this special category drinks likely to grow even faster through innovation. Juices, nectars and fruit drinks account for about one third of the beverage market in Poland. Their sales increased by $11.3 \%$ and $6.4 \%$, respectively, over the previous year, while customer expenditure increased by $8.4 \%$ and $1.7 \%$, respectively [1]. The observed increase in production is associated with higher industrial water consumption, implying higher volumes of waste water is being discharged into the environment [2].
In order to limit possible deterioration of water quality in receiving water bodies, the efficiency of treatment processes adopted in this industry should be consistently improved as the industry is expected to produce increasing wastewater quantities every year [3]. The most potentially harmful component of this flow is technological wastewater formed during washing of equipment and facilities, containing residuals of detergents, as well as other cleaning products [4], and is characterized by a great variability of pollutant concentrations over time. Its characteristics depend largely on the type of specific production, and by the adopted production cycle. For these reasons, industrial wastewater treatment plants (IWWTPs) are not designed according to classic process schemes adopted from municipal sewage treatment plants (MSTPs).

IWWTPs are characterized by an individual specificity deriving directly from quantity and quality (initial and expected) of treated wastewater, technology used in the industry, as well as specific operating conditions. Thus, the identification of a suitable solution for an IWWTP is relatively complex. The basic problem is to correctly determine amounts of incoming sewage, as well as pollutant loads, so that the plant will not be overly under or over-sized with respect to their foreseeable extended variability [5]. A proper solution should be resilient to such variability and perform consistently under any foreseeable circumstance.

Sewage treatment plants based on activated sludge technology face various operational problems. A main problem may be bulking of the sludge caused by excessive growth of filamentous bacteria [6]. Other

\footnotetext{
Corresponding author: j.boguniewicz@po.opole.pl
} 
problems could be due to the lack of sufficient amounts of organic compounds for the proper progress of the denitrification process [7]. As a result, deterioration of outflow quality may occur in treatment plants based on these processes. The solution may lay in the use of methanol or other chemicals dosed in the original wastewater order to improve treatment [8].

Inflow fluctuations and changes in pollutant concentration are additional problems in conventional activated sludge facilities. Under such conditions, Sequencing Batch Reactor (SBR) characterized by cyclic operation could be desirable. The major differences between SBR and conventional, continuous-flow, activated sludge system is that SBR tanks carry out equalization, aeration and sedimentation functions sequentially over time, rather than in the conventional space sequence of continuous-flow systems. Many studies $[9,10]$ demonstrate the efficiency of SBRs for organic matter and nutrients removal from wastewater, as well as the present one. Other growing technologies include Membrane BioReactors (MBRs) that are more frequently been used for both industrial and domestic wastewater treatment $[11,12]$.

Wastewater from the soft drink industry may include wasted soft drinks and syrup, water from bottles and cans washing, detergents and caustics, and traces of lubricants used in the production process machinery. These pollutants contain organic and inorganic substances described by the 5-day biochemical oxygen demand $\left(\mathrm{BOD}_{5}\right)$, and chemical oxygen demand (COD) [3]. Since wastewater from the soft drinks industry generally contains organic substances that are readily biodegradable [13], biological processes are mainly used for its treatment. The effectiveness/efficiency of the treatment depends on many factors, as described by Anielak [14] in a review of solutions and technologies for the treatment of food industry wastewater.

This paper presents an example of activated sludgebased IWWTP. Purpose of the study is to analyse the process of wastewater treatment in conditions of irregular inflow and varied composition. Treatment effectiveness was determined in terms of basic pollution indicators: $\mathrm{COD}, \mathrm{BOD}_{5}$ and Total Suspended Solid (TSS).

\section{Materials and methods}

\subsection{Characteristics of the specific IWWTP}

The sewage treatment plant object of this study has been thoroughly modernized, and put into operation back in 2010. Its maximum capacity is $1635 \mathrm{~m}^{3} / \mathrm{d}$, and the average flow of wastewater in 2015 was $805 \mathrm{~m}^{3} / \mathrm{d}$. Wastewater treatment is carried out with mechanical, biological and chemical processes to reach the desired quality objectives imposed by law [15] allowing its disposal into the environment.

Wastewater is pumped from a holding tank with a volume of $1500 \mathrm{~m}^{3}$ by two pumps with capacity of 55 $\mathrm{m}^{3} / \mathrm{h}$ to bar-and-mesh screens to hold large solids.
The so-called "sketches" are removed, transported by conveyor, dewatered and compacted in its final section. Wastewater then flows into the inner ring of the grit chamber, there sand settles to the bottom of the chamber. From this chamber the water-sand mix is pumped to a free-standing separator, where dehydration of the mix occurs, followed by the sand being dumped at a landfill. Quantitative and qualitative equalization of wastewater then occurs in a tank (active volume $175 \mathrm{~m}^{3}$ ) equipped with 3 pumps, feeding waste water from this to the biological block [16].

This consists of separation chamber, selector, activated sludge reactor, secondary clarifier and stabilization chamber. The biological processes block is divided into 3 identical technological lines. The system's scheme is illustrated in Fig. 1. Sewage aeration and degree of internal recirculation are controlled by an online oxygen meter. The recirculation system consists of a tank and two pipes equipped with shut-off valves. Separation of effluents from the activated sludge mixture occurs in secondary clarifier equipped with external recirculation pumps, feeding the settled solids to the selector. Waste sludge removed from the system is pumped to an aerobic stabilization chamber, where final stabilization of the sludge occurs by continued aeration, and stabilized sludge is then forwarded to a dewatering press.

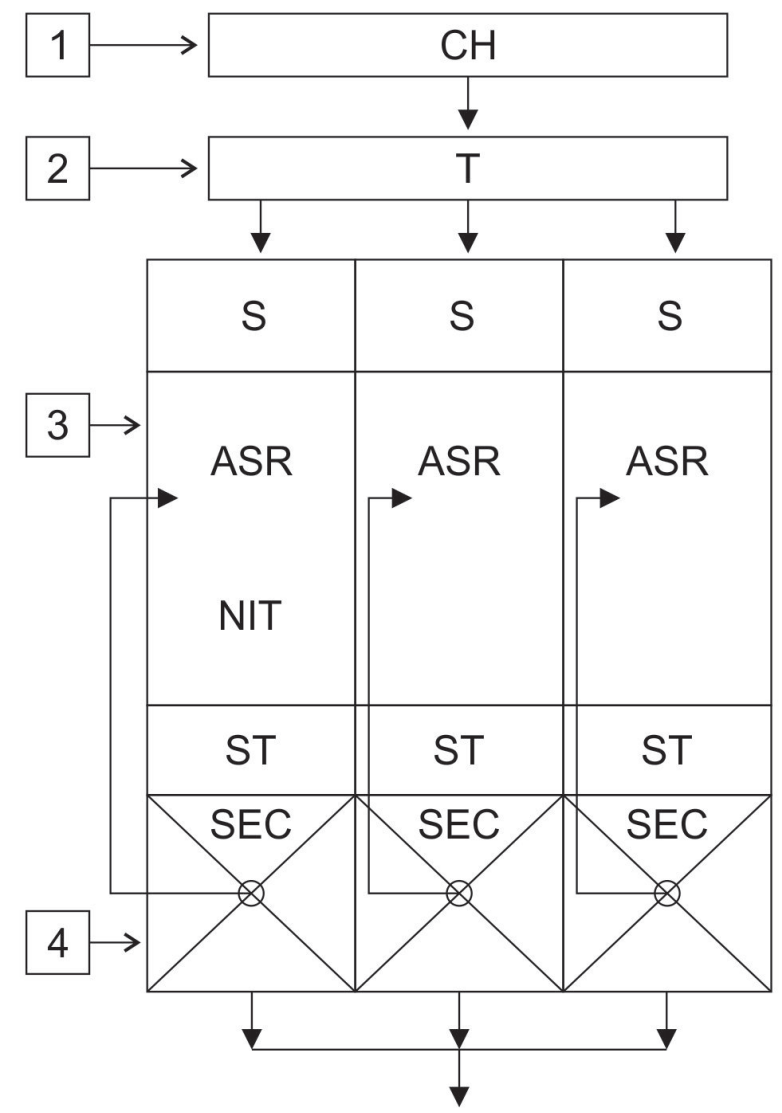

Fig. 1. Diagram of the biological part of wastewater treatment facilities where S- separation tank, ASR - activated sludge reactor (NIT- nitrification sector), ST - sludge thickener, SEC secondary clarifier, $\mathrm{CH}$ - chamber, T- neutralisation tank and Chemical addition: 1 - urea, 2- ammonium phosphate ,3methanol, and 4 - FLOKUAT TB54HC. 
The capacity of individual sections is: $40 \mathrm{~m}^{3}$ separation chamber, selector $170 \mathrm{~m}^{3}$, activated sludge reactor 1285 $\mathrm{m}^{3}$, secondary clarifier $216 \mathrm{~m}^{3}$ each (total $648 \mathrm{~m}^{3}$ ), sediment thickener $20 \mathrm{~m}^{3}$ (total $60 \mathrm{~m}^{3}$ ), sludge stabilization chamber $500 \mathrm{~m}^{3}$.

In biological part of IWWTP the wastewater flow is too low to ensure proper use of the tree activated sludge lines, at the same time the sludge loading with organic contaminants would be too low. Therefore there are only two aeration tanks in use. Internal recirculation is carried out separately for each tank.

\subsection{Characteristics of the receiving water body}

The treated wastewater is discharged to the Młynówka ditch, which reaches the Biała River after about 500 meters, a left tributary of Osobłogi R., which later flows into the Oder River in Krapkowice. The control point located on the Biała River, shows good ecological status and satisfies the requirements for protected waters [17].

\subsection{Methodology}

The procedures for wastewater sampling and the instrumentation used for water quality parameter measurements were determined according to recommendations of Polish State Sanitary Inspection. The spectrophotometer manufactured by $\mathrm{HACH}$ Co. model DR 2000 (Hach, Loveland, CO, USA) was applied for analysis of ammonium, nitrate, nitrite, and phosphorus (spectrophotomety VIS/UV). Hydrogen ion concentration $(\mathrm{pH})$ was measured with a $\mathrm{pH}$ meter. $\mathrm{BOD}_{5}$ was determined by dilution of samples and dissolved oxygen measurements by Winklers' method, and measurement of COD was conducted via a simplified dichromate method. TSS was filtered, placed into a $105^{\circ} \mathrm{C}$ oven to dry, and weighed. Some data was obtained directly from the company's.

To assess the effectiveness of the treatment facility, all monitoring data were used. The reduction ratio of individual pollutants was calculated using formula 1:

$$
\eta=\left(1-C_{e} / C_{o}\right) \times 100 \%
$$

where $\mathrm{C}_{0}$ is the concentration of the indicator in the raw wastewater and $\mathrm{C}_{\mathrm{e}}$ concentration in the treated effluent.

Flow values determined on the basis of measurements were: $\mathrm{Q}_{\text {avd }}=805.3 \mathrm{~m}^{3} / \mathrm{d}$; amount of raw sewage produced: $293934 \mathrm{~m}^{3} /$ year. It should be emphasized that the plant has a water permit for the discharge of treated industrial waste water to the Młynówka ditch in total amounts of $Q_{\text {avd }}=1150 \mathrm{~m}^{3} / \mathrm{d}$ and $\mathrm{Q}_{\operatorname{maxd}}=1635 \mathrm{~m}^{3} / \mathrm{d}$.

\section{Results and discussion}

An important factor influencing the efficiency of wastewater treatment processes is the intensity and variability of inflows and their characteristics. Due to frequent changes of organic compounds and nitrogen loads, problems with proper operation of the activated sludge process have been observed in the recent past, affecting treatment efficiency. The most frequently observed problem was an improper ratio of nitrogen and carbon in the influent solution, that was an impediment to the achievement of efficient biological treatment. This could have been due to the high percentage of "light" (or "diet") drink products, with lower sugar content compared with traditional drink products.

In this case, after some testing, it was determined that the best option was to introduce supplementary chemicals from the outside. Urea $(46 \% \mathrm{~N})$ in dosage of $90 \mathrm{~kg} / \mathrm{d}$ and ammonium phosphate $\left(40 \% \mathrm{P}_{2} \mathrm{O}_{5}\right.$ in diluted solution) at a dose of $50 \mathrm{~kg} / \mathrm{d}$ were therefore added to the neutralisation tank before biological treatment.

Furthermore, periodically, biological treatment presented poor sludge settling properties due to sludge bulking or poor floc aggregation (pinpoint sludge), losing biomass in the effluent with a deteriorating effect on the process. A loss of biomass implies also greater effluent organic loads, as $1 \mathrm{mg}$ of escaping biomass is approximately equivalent to $6 \mathrm{mg}$ additional COD in the effluent. The obvious solution for this, in the absence of a complete process revamping, is an occasional addition of coagulating chemicals, as seen required. In this facility, considerable efficiency improvements in removal of $\mathrm{BOD}_{5}$, COD were observed when the synthetic coagulant FLOKUAT TB54HC (proprietary name) was added at the effluent section of the aeration tank.

Fig. 2 shows the amount of sewage directed to the treatment plant compared to the volume of production, illustrating the fluctuation and ratios of sewage inflow to the treatment plant, following characteristic changes in the production of beverages. It can be seen that up to a drink production of about $10000 \mathrm{~m}^{3} /$ month, the amount of treated wastewater is roughly double that value, while for production levels $>10000 \mathrm{~m}^{3} /$ month, the volumes of treated wastewater is less than proportional to that quantity. In month VIII, when production of drink beverages was $20000 \mathrm{~m}^{3}$, water treatment stopped at $25000 \mathrm{~m}^{3}$, or just $25 \%$ more of the former. It seems that, at the lower production levels, the amount of process (and washing) water has an almost invariant generation pattern. It will be interesting to study if these volumes can further be optimized by enhanced internal operations, recycling or internal reuse.

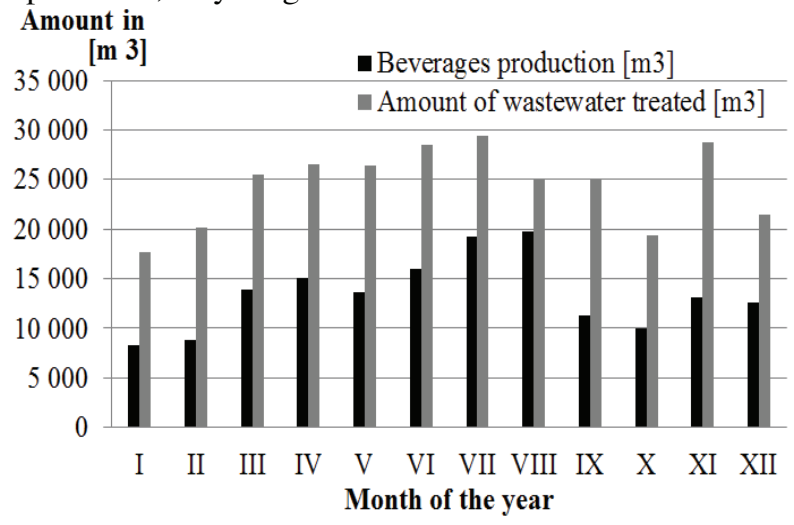

Fig. 2. The volumes of beverages production and amount of wastewater treated. 
Analyzing data presented in Fig. 2, significant fluctuations in the amount of monthly generated sewage, reaching up to $10000 \mathrm{~m}^{3}$, or $330 \mathrm{~m}^{3} / \mathrm{d}$ can be observed. The mean value of the inflow was $805 \mathrm{~m}^{3} / \mathrm{d}$ during the year in question. Minimum values of daytime inflows ranged from 500 to $600 \mathrm{~m}^{3} / \mathrm{d}$ in January and October, maximum value was about $900 \mathrm{~m}^{3} / \mathrm{d}$. A fluctuation of one third to one half of the volume of wastewater treated could warrant the study of alternative treatment strategies (i.e. temporary re-opening of the third line currently out of operation).

Table 1 shows pollutant concentration of sewage before biological treatment (after equalization tank with chemicals addition) and treated. The permissible values of the effluent parameters are in accordance with the Ordinance of the Minister of the Environment of 18 November 2014 [15] concerning the conditions to be met when discharging wastewater to water or land. The WWTP is obliged by permit to ensure the following quality of effluent wastewater: pH $6.5-9,0 ; \mathrm{BOD}_{5} \leq 25$ $\mathrm{mg} \mathrm{O}_{2} / \mathrm{l} ; \mathrm{COD}_{\mathrm{Cr}} \leq 125 \mathrm{mg} \mathrm{O}_{2} / \mathrm{l} ; \mathrm{TSS} \leq 35 \mathrm{mg} / \mathrm{l}$; Total Phosphorus $\leq 30 \mathrm{mg} \mathrm{P} / \mathrm{l}$; Total nitrogen $\leq 15 \mathrm{mg} \mathrm{N} / \mathrm{l}$; Ammonia nitrogen $\leq 0.124 \mathrm{mg} \mathrm{N}-\mathrm{NH}_{4} / 1$; or in alternative, to reduce the pollutants by: $\mathrm{BOD}_{5} \mathrm{~min} .90 \%$, $\mathrm{COD}_{\mathrm{Cr}} \min .92 \%$, TSS $\min .60 \%$.

Table 1. Mean values of wastewater pollutants concentrations before biological treatment (Inflow) and treated (Outflow).

\begin{tabular}{|c|c|c|c|c|c|}
\hline \multicolumn{2}{|c|}{ Sample } & 1 & 2 & 3 & 4 \\
\hline \multirow{2}{*}{$\begin{array}{c}\mathrm{BOD} \\
\mathrm{mg} \mathrm{O}_{2} / 1\end{array}$} & In & 304 & 321 & 626 & 408 \\
\hline & Out & 3.8 & 12 & 5.4 & 6.6 \\
\hline \multirow{2}{*}{$\begin{array}{c}\mathrm{COD} \\
\mathrm{mg} \mathrm{O}_{2} / 1\end{array}$} & In & 778 & 838 & 1216 & 1076 \\
\hline & Out & 18 & 98 & 30 & 75 \\
\hline \multirow{2}{*}{$\begin{array}{c}\mathrm{TSS} \\
\mathrm{mg} / 1\end{array}$} & In & 27 & 27 & 21 & 22 \\
\hline & Out & 17 & 14 & 7 & 16 \\
\hline \multirow{2}{*}{$\begin{array}{c}\mathrm{P} \\
\mathrm{mg} \mathrm{P} / 1\end{array}$} & In & 6 & - & 3 & 2 \\
\hline & Out & 4.8 & 5.2 & 1.8 & 5.4 \\
\hline
\end{tabular}

Removal efficiencies for $\mathrm{BOD}_{5}, \mathrm{COD}$, and total suspended solids (TSS) are shown in Fig. 3-5, in both situations on no chemicals support (A: before modification) and with chemicals additional dosages (B: after modification). $\mathrm{BOD}_{5}$ removal is improved in the latter case by at least $50 \%$, COD by at least $25 \%$.

$\mathrm{BOD}_{5}$ in treated wastewater ranges from 304 to $626 \mathrm{mg}$ $\mathrm{O}_{2} / 1$ during the year, according to the quantity and type of beverages produced. These fluctuations result in a high variations in total activated sludge biomass. The maximum $\mathrm{BOD}_{5}$ concentration occurs in September, at the same time the highest removal efficiency is reached, after process adjustment, at approximately $99 \%$. Therefore, the $\mathrm{BOD}_{5}$ parameter in the purified effluent never exceeds even half the allowable value. Without chemical addition, effluent values were consistently around the discharge limit.
A

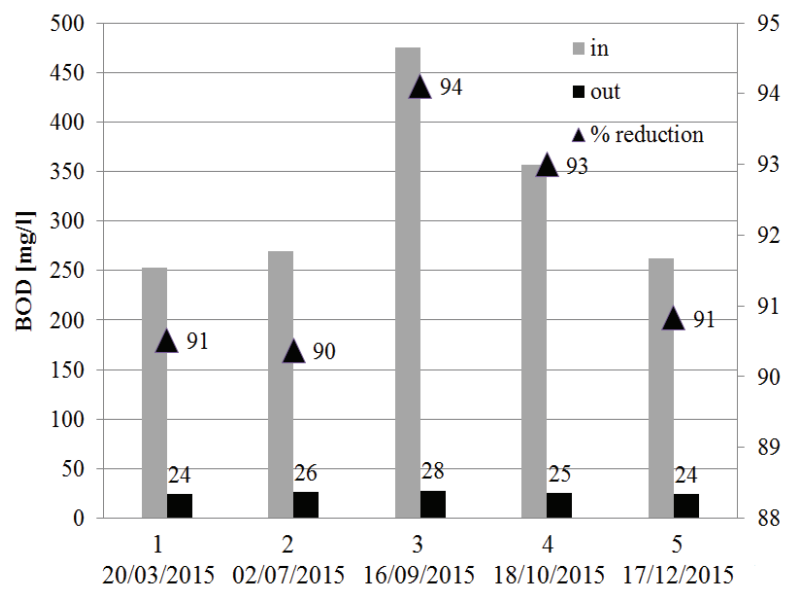

B

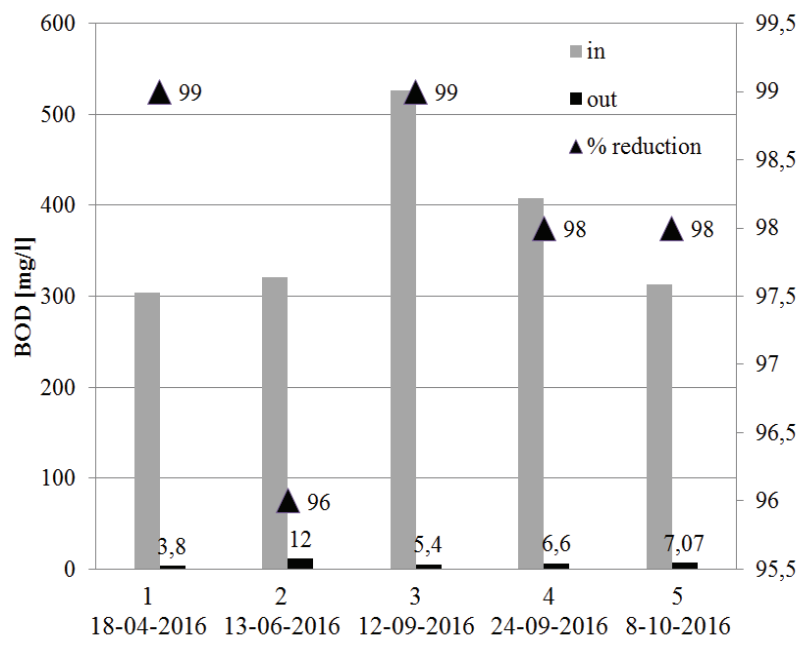

Fig. 3. Efficiency of $\mathrm{BOD}_{5}$ removal: (A) before modification; (B) after modification.

Similarly to $\mathrm{BOD}_{5}, \mathrm{COD}$ is also changing, the concentration before biological treatment of wastewaters ranging from 778 to $1216 \mathrm{mgO}_{2} / 1$. Its removal efficiency varies from $88 \%$ to $97 \%$, always fulfilling discharge limitations. Before chemical addition to the process, effluent values were mostly around, or above, effluent limits.

By comparing $\mathrm{BOD}_{5}$ and $\mathrm{COD}$ removals, it is easily appreciated that wastewater contains easily biodegradable organic substances. $\mathrm{BOD}_{5}$ to $\mathrm{COD}$ ratio, ranging between 0.3 and 0.6 , indicates susceptibility of sewage to biological treatment, although, as indicated by many papers $[9,10]$, knowledge of the participation of individual COD fractions allows for a more accurate assessment of the susceptibility of sewage to biological treatment than the overall quotient.

With regard to suspended solids, their removal efficiency is much smaller, but the limit values for outflows are not exceeded due to the low concentrations in the postproduction effluents. 
A

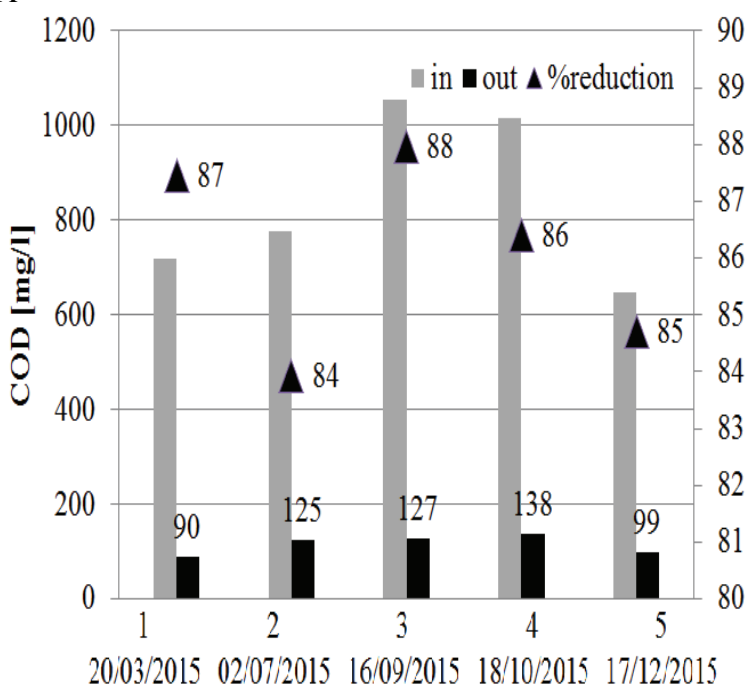

B

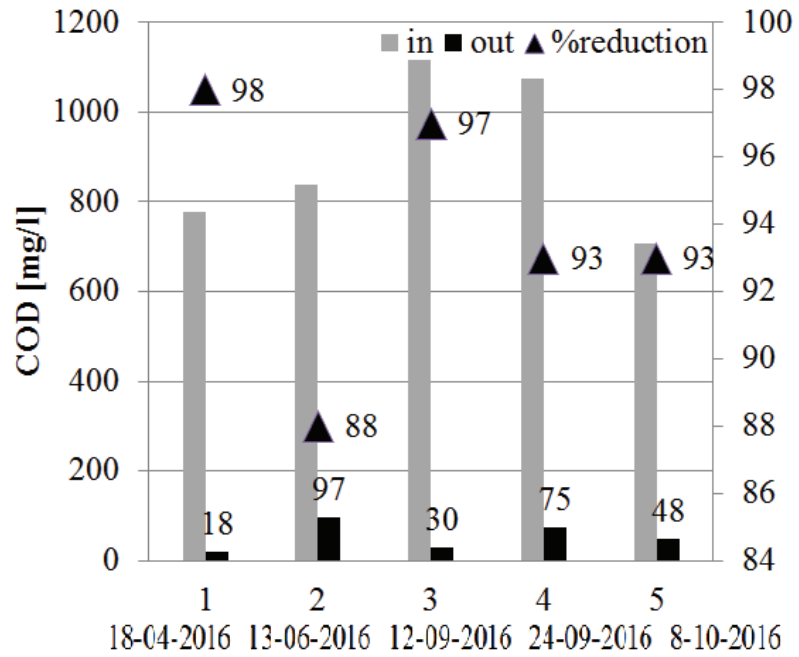

Fig. 4. Efficiency of COD removal: (A) before modification; (B) after modification.

This treatment facility is characterized by high removal efficiencies, after chemicals addition had been introduced, in agreement with values required by regulations. $\mathrm{BOD}_{5}$ on the outflow does not exceed 10 $\mathrm{mgO}_{2} / 1$, with values in inflow sewage up to 600.0 $\mathrm{mgO}_{2} / 1$, and efficiency between $96-98 \%$.

TSS effluent concentration is on average $15 \mathrm{mg} / \mathrm{l}$, with overall removal efficiency of $50 \%$ due to low inlet values at the treatment plant. COD was observed to decrease from $1216.0 \mathrm{mg} / \mathrm{l}$ to $30 \mathrm{mg} / \mathrm{l}$. Concentration of phosphorus in the effluent was up to $5 \mathrm{mgP} / \mathrm{l}$, with biological phosphorus removal periodically assisted by chemical precipitation with coagulant dosed into the effluent of the activated sludge reactor at a dose of 40-50 1/d of PIX (ferric chloride) coagulant.

This is most important in the spring when excessive effluent $\mathrm{P}$ concentrations can cause euthrophication in receiving waters. Similar threats have already been described by many authors including Capodaglio $[18,19]$, Zhang [20], and others [13,21]

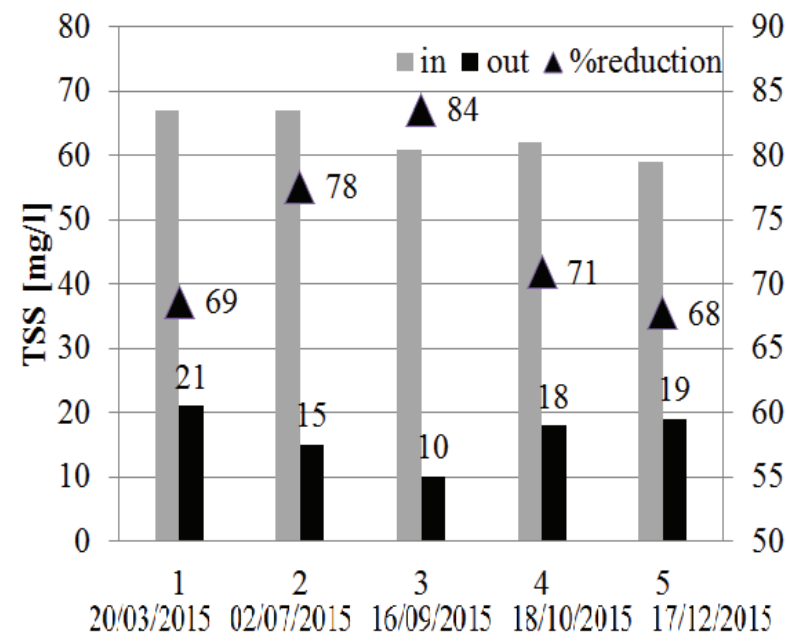

B

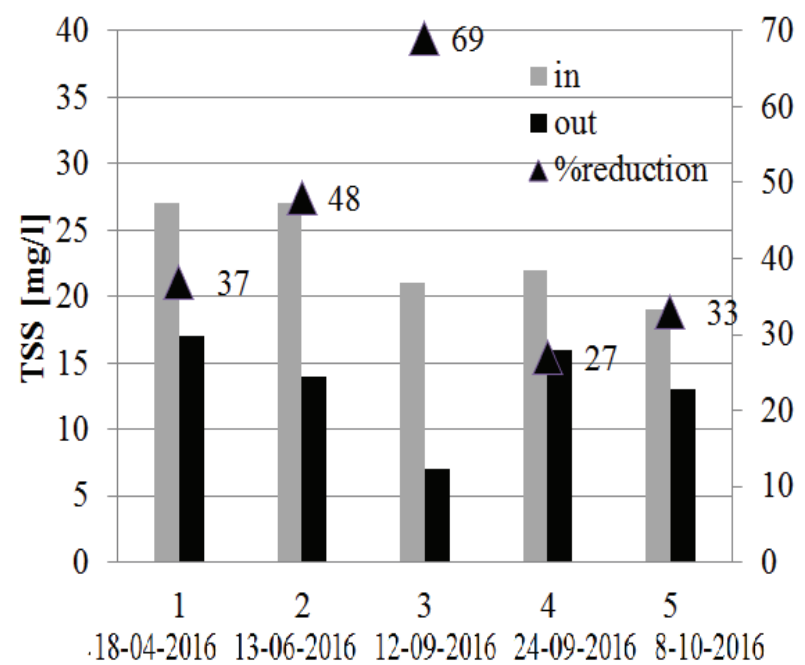

Fig. 5. Efficiency of TSS removal : (A) before modification; (B) after modification.

While in this case, biological treatment was assisted by external dosage of chemicals, as required to improved treatment efficiency, an alternative solution to chemicals dosing, could gave consisted in configuration changes of wastewater treatment process sequence. Such changes could involve replacing one aeration chamber with denitrification chamber.

However, since frequent problems had been observed due the lack of organic carbon in the influent, achievement of good biological denitrification could have not been assured. This would have required also the addition of supplemental carbon, which was considered an un-appropriate choice. There are many different compounds that could be used to aid in denitrification. Among the most commonly used, and best documented is methanol $[9,22]$.

Another solution could also have been the adoption of the pre-denitrification stage. Such a scheme will be tested in this industrial wastewater treatment plant to evaluate effectiveness and cost-efficiency. 


\section{Conclusions}

It is usually cheaper, technically simpler and more efficient to clean industrial effluents at the source, rather than attempting their treatment after mixing/dilution with household effluent. However, due to the fluctuation of pollutant loads from industrial plants, and especially in smaller facilities, constant monitoring of process parameters and careful efficiency evaluation of individual steps is required. Production changes significantly affect the removal efficiency of the main parameters: organic compounds, nitrogen and phosphorus. Biological treatment could be assisted by the dosage of chemicals, as required, to avoid effluent deterioration. The addition of chemicals to assist treatment processes in this case was considered an optimal choice to support industrial wastewater treatment in sub-optimal conditions. A predenitrification process option was however considered as an alternative solution and will soon be tested as it could effectively eliminate the necessity of chemicals addition. The wastewater treatment plant object of this evaluation can provide complete treatment of wastewater in accordance with the requirements of the Regulation of the Minister of the Environment of 18 November 2014. The purified effluent parameters are lower than the required values and their quantity and quality do not adversely affect the receiver.

\section{References}

1. PAIiIZ. Food industry in Poland. Polish Agence of Information and Investments S.A. (2013) (in Polish)

2. L.L. Fillaudeau, P. Blanpain-Avet, G. Daufin, J. Cleaner Prod. 14, 5 (2006)

3. J. Chen, S. Seng, Y. Hong, Wastewater Treatment, 7, pp. 255-269, (AG-Metal Zenica, Taylor \& Francis Group, LLC, 2006)

4. E. Podgórni., J. Boguniewicz-Zabłocka, Aplikacyjne i teoretyczne problemy w przemyśle rolno-spożywczym - postęp naukowo-techniczny, Politechnika Opolska, pp. 205-214 (2016) (in Polish)

5. B. Bartkiewicz, Industrial Wastewater Treatment, (WN PWN, Warszawa, 2006) (in Polish)

6. A.G. Capodaglio, H. Jones, V. Novotny, X. Feng, Water Res 25(10), 1217-1224, (1991)

7. A.G. Capodaglio, P. Hlavínek, M. Raboni, Ambiente \& Áqua - Interdisciplinary J. Appl. Sci. (2016)

8. Z. Heidrich, Water and wastewater management guide, (Verlag Dashofer, Warszawa, 2012) (in Polish)

9. A. Anielak, Unconventional methods of nutrients removal in SBR reactors. Gaz, woda i technika sanitarna (in Polish) (2006)

10. W. Dąbrowski, M. Puchlik, Ochrona Środowiska, 12, 735-746 (2010)
11. A.G. Capodaglio, A. Callegari, Water Practice Technol. 10,3 (2015)

12. A.G. Capodaglio, A. Callegari, J. Water, Sanitation Hyg. Dev. 6, 3 (2016)

13. T. Imoobe and P. Okoye, J. Pure Appl. Sci. 4, 1, (2011)

14. A. Anielak, Dairy industry and its water-sewage economics, Agro Przemysł 2, 57-59 (in Polish), (2008)

15. Ordinance of the Minister of the Environment of Poland of 18 November 2014 (Journal of Laws no1800)

16. D. Vogel, Diploma Thesis, Politechnika Opolska (2017) [in Polish]

17. State of the environment in Poland. Main Inspectorate for Environmental Protection, Library of Environmental Monitoring, (2015) Access 12.12.2016,http://www.gios.gov.pl//zalaczniki/artyk uly/Sygnaly\%20 calosc_pol2015.pdf. [in Polish]

18. A.G. Capodaglio, J. Boguniewicz, F. Salerno, E. Lorents, D. Copetti, E. Legnani, G. Tartari, River Basin Management - Lawson (ed.) (ICE, London, ISBN 0415 392004, 2005)

19. A.G. Capodaglio, A. Muraca, G.Becchi, Water Sci. Technol. 47, p. $291-298$ (2003)

20. R.B. Zhang, X. Qian, X.C. Yuan, R. Ye, B.S. Xia, and Y.L. Wang, Int. J. Environ. Res. Public Health 9, 4504-4521 (2012)

21. A.Azzellino, R.Salvetti, R.Vismara, L.Bonomo, Sci. Tot. Environ. 371 214-222 (2006)

22. K.R. Pagilla, M. Urgun-Demitras, R. Ramani, Water Sci. Technol. 53, 3, 165-17 (2006) 